\title{
Relaxin (RLX) and estrogen affect estrogen receptor $\alpha$, vascular endothelial growth factor, and RLX receptor expression in the neonatal porcine uterus and cervix
}

\author{
Wenbo Yan, Joseph Chen, Anne A Wiley ${ }^{1}$, Bethany D Crean-Harris ${ }^{1}$, Frank F Bartol ${ }^{1,2}$ \\ and Carol A Bagnell \\ Department of Animal Sciences, Rutgers, The State University of New Jersey, New Brunswick, New Jersey 08901, \\ USA, Departments of ${ }^{1}$ Animal Sciences and ${ }^{2}$ Anatomy, Physiology and Pharmacology, Cellular and Molecular \\ Biosciences Program, Auburn University, Auburn, Alabama 36849, USA
}

Correspondence should be addressed to C A Bagnell; Email: bagnell@aesop.rutgers.edu

W Yan and J Chen contributed equally to this work

\begin{abstract}
The porcine female reproductive tract undergoes estrogen receptor (ER) $\alpha$-dependent development after birth (postnatal day=PND 0), the course of which can determine adult uterine function. Uterotrophic effects of relaxin (RLX) in the porcine neonate are age specific and may involve ER activation. Here, objectives were to determine effects of RLX and estrogen administered from birth on uterine and cervical growth and expression of ER $\alpha$, vascular endothelial growth factor (VEGF), and the RLX receptor (RXFP1). On PND 0, gilts were treated with the antiestrogen ICI 182780 (ICI) or vehicle alone and, $2 \mathrm{~h}$ later, were given estradiol-17 $\beta$ (E) or porcine RLX for 2 days. Neither RLX nor E affected uterine wet weight or protein content on PND 2. However, RLX, but not E, increased cervical wet weight and protein content when compared with controls. Pretreatment with ICI did not inhibit RLX-stimulated cervical growth. Uterine and cervical ER $\alpha$ increased in response to RLX, but not E. Both RLX and E increased VEGF in the uterus and cervix on PND 2. Pretreatment with ICI increased VEGF in both tissues and increased RLX-induced cervical VEGF. In the uterus E, but not RLX, increased RXFP1 mRNA. In the cervix, E increased RXFP1 gene expression whereas RLX decreased it. Results indicate that the neonatal uterus and cervix are sensitive to E and RLX and that growth responses to RLX in these tissues differ by PND 2. Effects of RLX on uterine and cervical ER $\alpha$ and VEGF expression may be important for neonatal reproductive tract development.

Reproduction (2008) 135 705-712
\end{abstract}

\section{Introduction}

Growth of the female reproductive tract (FRT) is sensitive to both estrogen and relaxin (RLX; Vasilenko \& Mead 1987, Cullinan-Bove \& Koos 1993, Hall \& Anthony 1993, Pillai et al. 1999), and organizational events responsible for both tissue patterning and programming are estrogen receptor (ER) dependent (Couse \& Korach 1999, Tarleton et al. 1999). Thus, factors that affect ER expression and activation can determine the developmental trajectory of these tissues (Schonfelder et al. 2002, Suzuki et al. 2002, Nikaido et al. 2005). Evidence that ER antagonists block uterotrophic effects of RLX in the rat (Pillai et al. 1999) and neonatal pig (Yan et al. 2006a) and that RLX is required to support myometrial ER $\alpha$ expression in RLX-null mice (Siebel et al. 2003) indicates that RLX should be included in the list of factors with the potential to affect FRT programming.

It is well established that patterns of ER expression in FRT tissues are regulated both temporally and spatially during the course of development (Yamashita et al. 1989, Glatstein
\& Yeh 1995, Mowa \& Iwanaga 2000, Okada et al. 2005). Moreover, aberrant activation of the ER system can have lasting consequences for FRT morphology and function (Miller et al. 1998, Markey et al. 2005). In the pig, this is supported by evidence that the neonatal uterus: i) is $E R \alpha-$ negative at birth (Tarleton et al. 1998); ii) develops sensitivity to estrogen between birth (postnatal day $=$ PND 0) and PND 15 that is associated with the appearance and proliferation of endometrial glands and the expression of $E R \alpha$ in the stroma and glandular epithelium (Tarleton et al. 1998, 2001); and iii) responds to transient estrogen exposure from birth with affects on adult phenotype, uterine responses to conceptus signals, and uterine capacity to support pregnancy (Tarleton et al. 2001, 2003).

Following identification of the cognate RLX receptor (LGR7; Hsu et al. 2002), now designated RLX family peptide receptor 1 (RXFP1; Bathgate et al. 2006), its expression was confirmed in the neonatal uterus at birth, prior to the onset of ER $\alpha$ expression (Yan et al. 2006b). 
Taken together with evidence that uterotrophic effects of both estrogen (Spencer et al. 1993, Tarleton et al. 2001) and RLX become more pronounced with age between birth and PND 15 (Yan et al. 2006a), these observations indicated that functional ER $\alpha$ and RLX receptor systems evolve in neonatal porcine FRT tissues during the first days of neonatal life. Recent studies showed that RLX is absent from the neonatal circulation at birth, prior to nursing, but is present in colostrum or first milk at the time of parturition and is likely transmitted into the neonatal circulation during the first $48 \mathrm{~h}$ of postnatal life as a consequence of nursing (Yan et al. 2006b). Therefore, a maternally driven lactocrine mechanism was hypothesized whereby milkborne RLX, absorbed into the neonatal circulation during the first days of postnatal life, could act directly through RXFP1 and/or indirectly through the evolving ER system to influence developmental programming events in the neonate (Yan et al. 2006b).

Trophic effects of RLX on reproductive tissues, including the uterus, cervix, and vagina of prepubertal and adult animals are well documented (Sherwood 2004). Given that all of the components of a classical RLX signaling system are present in neonatal gilts at birth (Yan et al. 2006a), and that functional crosstalk between RLX and estrogen signal transduction systems is likely to influence FRT growth (Pillai et al. 1999, Yan et al. 2006a), studies now focus on the impact of these hormones on FRT development during early postnatal life. Here, objectives were to determine short-term effects of RLX and estradiol-17 $\beta$ (E), administered for 2 days from birth, on FRT growth and the expression of $E R \alpha$, vascular endothelial growth factor (VEGF), a marker of estrogen (Cullinan-Bove \& Koos 1993) and RLX (Unemori et al. 1999) action, and RXFP1 in the uterus and cervix of neonatal gilts.

\section{Results \\ Uterine and cervical tissue wet weights and protein content}

When administered from birth, neither $E$ nor RLX affected uterine wet weight as determined on PND 2 (Fig. 1A). Although $E$ also had no effect on cervical wet weight, RLX treatment increased $(P<0.01)$ cervical wet weight when compared with controls (Fig. 1B). Pretreatment of gilts with $\mathrm{ICl}$ did not influence the RLX-induced cervical weight gain. Results for uterine and cervical protein content mirrored those obtained for tissue wet weight data, in that neither RLX nor E affected uterine protein content (Fig. 2A) whereas RLX, but not E, increased $(P<0.01)$ cervical protein content on PND 2 when compared with controls (Fig. 2B). Pretreatment with $\mathrm{ICI}$ had no effect on the RLX-induced increase in cervical protein content on PND 2.
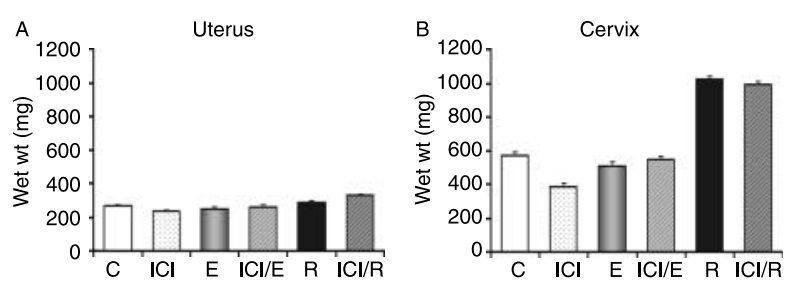

Figure 1 Treatment effects on $(A)$ uterine and (B) cervical wet weight on PND 2. Data are expressed as LSM \pm s.E.M. ( $n=$ three to eight animals per group). Body weight was included as a covariate in statistical analyses. Results of preplanned contrasts follow for uterus and cervix: $\mathrm{C}$ versus $\mathrm{E}(P<0.5$ and 0.41$), \mathrm{C}$ versus $\mathrm{R}(P<0.4$ and 0.01$)$, E versus $\mathrm{ICl} / \mathrm{E}(P<0.69$ and 0.71$), \mathrm{R}$ versus $\mathrm{ICl} / \mathrm{R}(P<0.15$ and 0.65$)$, and E versus $\mathrm{ICI}(P<0.65$ and 0.14$)$ respectively.

\section{Uterine and cervical expression of ER $\alpha$ and VEGF protein}

Representative Western blots and results of densitometric analyses for ER $\alpha$ and VEGF are presented in Figs 3 and 4. Treatment with RLX, but not $E$, from birth increased $(P<0.04)$ the relative abundance of uterine $E R \alpha$ protein on PND 2 when compared with controls (Fig. 3A and B). Likewise, RLX, but not $\mathrm{E}$, increased $(P<0.01)$ cervical ER $\alpha$ expression on PND 2 (Fig. 3C and D). Responses to RLX and $\mathrm{E}$ were unaffected by pretreatment with $\mathrm{ICl}$ in either the uterus or cervix (Fig. 3).

The relative abundance of dimeric VEGF protein (46 kDa) in both uterine (Fig. 4A and B) and cervical tissues (Fig. 4C and D) increased in response to RLX $(P<0.01)$ and $\mathrm{E}(P<0.01)$ when compared with controls on $P N D$ 2. Interestingly, treatment with $\mathrm{ICl}$ alone increased VEGF expression in both the uterus $(P<0.02)$ and cervix $(P<0.01$ ). For the uterus (Fig. 4B), ICl pretreatment had a marginal negative effect on E-induced VEGF expression $(P<0.07)$. By contrast, pretreatment with $\mathrm{ICl}$ increased $(P<0.01)$ RLX-induced cervical VEGF expression (Fig. 4D).

\section{Uterine and cervical expression of RXFP1 mRNA}

Data illustrating effects of $E$ and RLX administered for 2 days from birth on uterine and cervical RXFP1 gene expression in gilts on PND 2 are presented in Fig. 5. In the
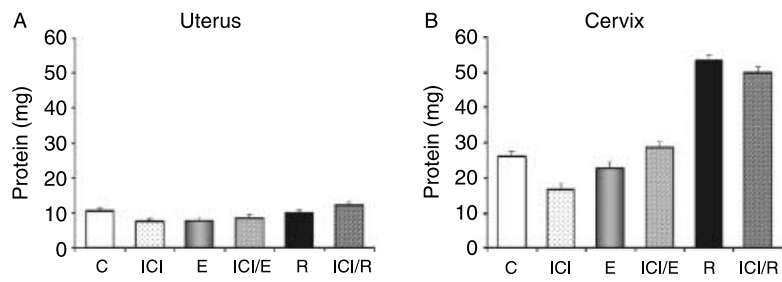

Figure 2 Treatment effects on (A) uterine and (B) cervical protein content on PND 2. Total protein content for each tissue is expressed as LSM \pm S.E.M. ( $n=$ three to eight animals per group). Results of preplanned contrasts follow for uterus and cervix: $C$ versus $E(P<0.36$ and 0.54$), C$ versus $R(P<0.89$ and 0.01$)$, E versus $\mathrm{ICI} / \mathrm{E}(P<0.78$ and $0.31)$, $\mathrm{R}$ versus $\mathrm{ICI} / \mathrm{R}(P<0.42$ and 0.56$)$, and $\mathrm{E}$ versus $\mathrm{ICI}(P<0.92$ and $0.35)$ respectively. 
A

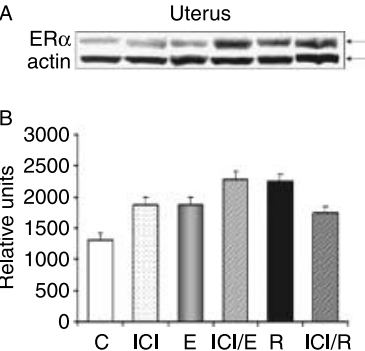

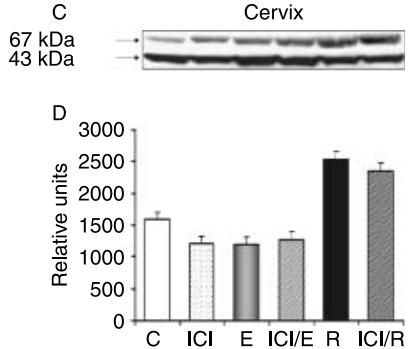

Figure 3 Treatment effects on (A) uterine and (B) cervical $E R \alpha$ expression on PND 2. (A and C) Representative Western blots for individual animals for each tissue and treatment category. Both $67 \mathrm{kDa}$ and $43 \mathrm{kDa}$ bands indicative of immunoreactive $\mathrm{ER} \alpha$ and $\beta$-actin (included as a loading reference), respectively, are indicated ( $B$ and D). Summaries of densitometric data for ER protein expressed as LSM \pm S.E.M. ( $n=$ three to eight animals per group). Data were adjusted for potential loading variation by including data for actin as a covariate in statistical analyses. Results of preplanned contrasts follow for uterus and cervix: $C$ versus $\mathrm{E}(P<0.28$ and 0.92$), \mathrm{C}$ versus $\mathrm{R}(P<0.04$ and $0.01), \mathrm{E}$ versus ICI/E $(P<0.35$ and 0.78$), \mathrm{R}$ versus $\mathrm{ICI} / \mathrm{R}(P<0.24$ and $0.75)$, and $\mathrm{E}$ versus $\mathrm{ICI}(P<0.82$ and 0.55$)$ respectively.

uterus (Fig. 5A), E increased $(P<0.01) R X F P 1$ mRNA levels when compared with tissues obtained from controls. By contrast, RLX did not affect uterine RXFP1 gene expression (Fig. 5A). In the cervix (Fig. 5B), E induced an increase $(P<0.06)$ in RXFP1 gene expression, whereas RLX induced a decrease $(P<0.01)$ in this response.

\section{Discussion}

While trophic effects of RLX on the reproductive tract are well documented (Sherwood 2004), the mechanism of RLX action in promoting uterine and cervical growth remains elusive. In this study, we report differential
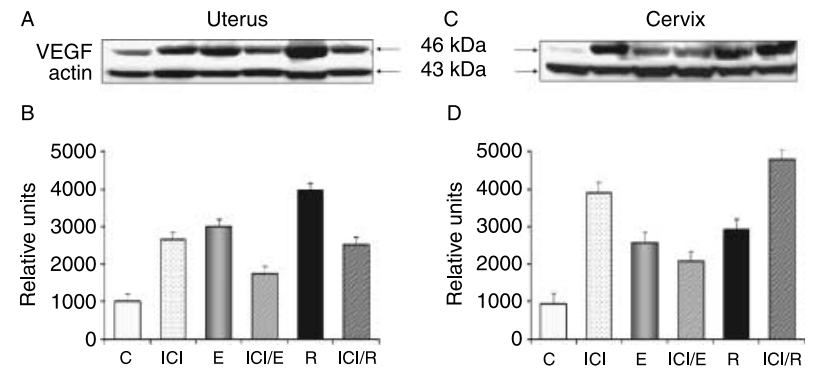

Figure 4 Treatment effects on $(A)$ uterine and $(B)$ cervical VEGF protein on PND 2. (A and C) Representative Western blots for individual animals for each tissue and treatment category. Both 46 kDa and $43 \mathrm{kDa}$ bands indicative of immunoreactive VEGF and $\beta$-actin (included as a loading reference), respectively, are indicated ( $B$ and D). Summaries of densitometric data for VEGF protein expressed as LSM \pm s.E.M. ( $n=$ three to eight animals per group). Data for VEGF were adjusted for potential loading variation by including data for actin as a covariate in statistical analyses. Results of preplanned contrasts follow for uterus and cervix: $C$ versus $\mathrm{ICI}(P<0.02$ and 0.01$), \mathrm{C}$ versus $\mathrm{E}$ $(P<0.01$ and 0.01$), \mathrm{C}$ versus $\mathrm{R}(P<0.01$ and 0.01$), \mathrm{E}$ versus $\mathrm{ICI} / \mathrm{E}$ $(P<0.07$ and 0.33$), \mathrm{R}$ versus $\mathrm{ICI} / \mathrm{R}(P<0.05$ and 0.01$)$, and $\mathrm{E}$ versus $\mathrm{ICI}$ $(P<0.73$ and 0.67$)$ respectively.
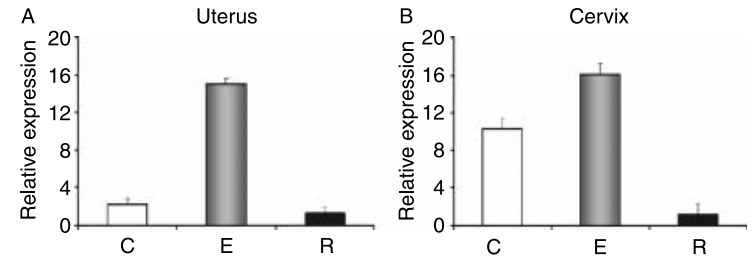

Figure 5 Treatment effects on (A) uterine and (B) cervical RXFP1 mRNA on PND 2. Data are expressed as LSM \pm s.E.M. ( $n=$ four animals per group). Results of preplanned contrasts follow for uterus and cervix: $C$ versus $\mathrm{E}(P<0.01$ and 0.06$), \mathrm{C}$ versus $\mathrm{R}(P<0.52$ and 0.01$)$, and E versus $\mathrm{R}(P<0.01$ and 0.01$)$ respectively.

effects of RLX on the uterus and cervix in the neonatal pig, in which both ER $\alpha$ (Tarleton et al. 1998) and RXFP1 expression are developmentally regulated (Yan et al. 2006b). Previous studies showed that the neonatal gilt is sensitive to uterine growth-promoting actions of RLX and that neonatal uterotrophic responses to RLX are both age specific and related functionally to the relative presence and state of activation of the ER $\alpha$ system (Yan et al. 2006a). For example, RLX, administered to gilts for 2 days from birth, increased uterine luminal epithelial height, but not uterine weight or protein content, on PND 2. By contrast, administration of RLX for 2 days beginning on PND 12, after the onset of uterine ER $\alpha$ expression, increased uterine weight, protein content, and luminal epithelial height on PND 14 (Yan et al. 2006a). Moreover, the latter effects were inhibited by pretreatment with $\mathrm{ICl}$. These findings were consistent with data for rats showing that RLX-stimulated uterine edema is ER dependent (Pillai et al. 1999).

In the present study, when treatments were initiated on PND 0, RLX increased cervical but not uterine wet weight and protein content. Additionally, cervical responses to RLX were not affected by pretreatment with $\mathrm{ICl}$. These data suggest that tissue-specific trophic actions of RLX observed in the cervix of newborn gilts are unlikely to involve crosstalk with the ER signaling system at this early postnatal stage of development. Whether ER activation is involved in RLX-stimulated cervical growth later in life remains to be investigated.

$E R \alpha$ expression was detected in both uterine and cervical tissues by PND 2 and increased in response to RLX administered from birth. To our knowledge, this is the first report that RLX increases ER $\alpha$ expression in vivo. Observations are consistent with the fact that, in the absence of RLX, myometrial ER $\alpha$ expression was attenuated in RLX-null mice during late pregnancy (Siebel et al. 2003). By contrast, studies in rats have shown that RLX decreased uterine $E R \beta$ (ESR2) mRNA levels without affecting $E R \alpha$ (ESR1) mRNA levels (Pillai et al. 2002). Moreover, in the cervix and vagina of RLX-null mice, chronic infusion of RLX had no effect on $E R \alpha$ gene expression and decreased $E R \beta$ mRNA in late gestation (Parry et al. 2005). Although low uterine $E R \beta$ gene expression in adult porcine tissues has been 
reported (Cardenas \& Pope 2005), there is no evidence for porcine uterine expression of ER $\beta$ protein in the first 2 weeks of neonatal life (Yan et al. 2006a). Collectively, these observations reinforce the importance of comparative studies. Data clearly support the idea that RLX can affect patterns of ER expression in target tissues.

Although ER $\alpha$ protein was detectable in the uterus and cervix by PND 2, there was no evidence that treatment with $\mathrm{ICl}$ alone affected uterine or cervical ER $\alpha$ protein expression. For the uterus, this may be explained by the fact that ICI treatment was administered on PND 0, when uterine $\mathrm{ER} \alpha$ expression is low to undetectable (Tarleton et al. 1998, Yan et al. 2006a), whereas tissues were obtained on PND 2. Data describing the ontogeny of porcine cervical $E R \alpha$ expression from birth are sorely lacking. However, if data for the uterus provide a valid reference, the absence of a detectable effect of $\mathrm{ICI}$ on $E R \alpha$ expression in neonatal FRT tissues observed here should not be surprising. Absence of a fully functional $E R \alpha$ signaling system may also explain why pretreatment with $\mathrm{ICl}$ did not affect uterine or cervical ER $\alpha$ expression in response to $\mathrm{E}$ or RLX.

Results also indicated that VEGF expression can be used as a marker of both E and RLX action in neonatal porcine uterine and cervical tissues. Moreover, present data suggest that VEGF expression is a more sensitive marker of $E$ action in the uterus and cervix on PND 2 than either organ wet weight or protein content. The fact that RLX stimulates both uterine and cervical VEGF expression in the neonate is consistent with similar evidence for angiogenic activity and/or VEGF expression in human endometrial stromal cells (Unemori et al. 1999), in the marmoset endometrium of pregnancy (Einspanier 2001) and at wound sites (Unemori et al. 2000).

Since $\mathrm{ICl}$ alone did not influence uterine or cervical wet weight, protein content, or ER $\alpha$ protein expression in gilts on PND 2, the observed positive effects of $\mathrm{ICl}$ on both uterine and cervical VEGF protein expression were somewhat unexpected. However, $\mathrm{ICl}$ alone was also found to increase uterine epithelial proliferation, as reflected by an increase in proliferating cell nuclear antigen (PCNA) labeling index, in gilts on PND 14 (Masters et al. 2007). Such effects may be explained by the fact that $\mathrm{ICl}$ can alter the transcription of estrogenresponsive genes via activation of SP1 promoter elements (Kim et al. 2003, Fleming et al. 2006). Like PCNA (Shipman-Appasamy et al. 1991), VEGF expression is positively regulated by SP1 activation (Milanini et al. 1998, Shi et al. 2001). A gene expression profiling study of mammary epithelial cells revealed 268 genes for which expression was regulated via a nonclassical $E R \alpha$ pathway (Glidewell-Kenney et al. 2005). The largest number of these genes, including some for which expression was not responsive to $E$, were activated by ICI (Glidewell-Kenney et al. 2005). Clearly, effects of $\mathrm{ICl}$ are complex, not necessarily or exclusively antiestrogenic, and may be biologically context dependent. This may explain, at least in part, the agonist-like effects of ICl observed here for VEGF protein expression.

Given that objectives of the present study included evaluation of the short-term effects of $E$ and RLX administered from birth on uterine and cervical responses, effects of these treatments on RXFP1 expression in these tissues were evaluated. Moreover, while uterine RXFP1 expression was documented in tissues obtained at birth (Yan et al. 2006b), similar data for neonatal porcine cervical tissues are lacking. The fact that $\mathrm{E}$ administered from birth increased RXFP1 expression in both the uterus and cervix on PND 2 supports and extends previous studies indicating the importance of estrogen in sensitizing reproductive tissues to RLX (Mercado-Simmen et al. 1982, Downing \& Hollingsworth 1992, 1993). Results are consistent with the idea that estrogen priming can facilitate (Vasilenko et al. 1980, Vasilenko \& Mead 1987) or enhance responsiveness of RLX target tissues (Adams et al. 1989). The observation that cervical RXFP1 expression on PND 2 was reduced following RLX administration from birth is new. These data are consistent with studies reported in rats in which infusion of unlabeled RLX reduced uterine and cervical uptake of radiolabeled RLX when compared with saline-infused controls (Downing \& Hollingsworth 1993). Likewise, in RLX-null mice, both cervical and vaginal RXFP1 expression increased during late pregnancy when compared with RLX-replete wild-type controls (Parry et al. 2005). Furthermore, continuous infusion of RLX for 6 days in pregnant RLX-null mice decreased cervical and vaginal RXFP1 mRNA levels on gestation day 18.5 when compared with saline-treated RLX-null controls (Parry et al. 2005).

Collectively, these studies point to a potential negative regulatory mechanism through which RLX downregulates the expression of its own receptor. In studies of human endometrial cells, RLX had no effect on endometrial stromal RXFP1 expression while RLX increased RXFP1 mRNA in a dose- and time-dependent fashion in decidual cells collected at term (Mazella et al. 2004). However, using endometrial stromal cells under conditions known to promote decidualization in vitro, Ivell and colleagues reported that RLX did not influence RXFP1 transcript levels (Bartsch et al. 2004). This is consistent with data presented here showing that RLX had no effect on uterine RXFP1 expression in vivo. The explanation for these differences in effects of RLX on RXFP1 expression remains unclear but may be due to differences between species, endocrinological status of the tissues, and/or experimental conditions.

In conclusion, data presented here show that the neonatal porcine uterus and cervix are differentially sensitive to $E$ and RLX from birth. In addition, effects of $E$ and RLX on cognate RLX receptor expression during this period of neonatal life are tissue specific. This study also 
provides further evidence for the interaction between $\mathrm{E}$ and RLX signaling pathways in which RLX stimulates $E R \alpha$ expression and $E$ increases RXFP1 expression in the uterus and cervix of neonatal pigs. The fact that $E$ and RLX presented to neonatal gilts from birth can increase uterine and cervical ER $\alpha$ expression by PND 2 has significant developmental implications. While the importance of ER $\alpha$ activation for cervical development remains to be investigated, it is clear that postnatal $E R \alpha$ expression is required for normal uterine growth and endometrial development (Bartol et al. 2006). Recent studies also showed that the neonatal uterus is RXFP1positive at birth, that RLX is present in porcine milk from the first day of lactation, and that RLX is detectable in the peripheral circulation of nursing pigs within $48 \mathrm{~h}$ of birth (Yan et al. 2006b). Taken together with present observations, these data suggest that critical early events associated with growth, development, and programming of FRT tissues in the neonatal pig could be facilitated through the actions of milk-borne RLX delivered to the neonate from the maternal system via a lactocrine mechanism (Yan et al. 2006b).

The extent to which RLX or other milk-borne growth factors may be affecting the development of FRT or other RLX receptor-positive somatic tissues is unknown. Studies are underway to determine if the absence of milk-borne growth factors from birth, including RLX, affects early neonatal uterine or cervical gene expression events associated normally with FRT development and, if so, whether resulting phenotypes can be rescued by repletion of RLX or milk.

\section{Materials and Methods}

\section{Materials}

Porcine RLX (CM-A fraction; $3000 \mathrm{U} / \mathrm{mg}$ ) was prepared at the Department of Biomedical Sciences (University of Guelph, Ontario, Canada) by extraction and purification from the ovaries of pregnant sows (Sherwood \& O'Byrne 1974). Purity was confirmed by SDS-PAGE, which revealed a single band at $\sim 6.2 \mathrm{kDa}$. Biological activity of the RLX preparation was ascertained by inhibition of spontaneous uterine motility in vitro (Wiqvist \& Paul 1958) and immunoreactivity was verified by RIA (Porter et al. 1992). Estradiol-17 $\beta$ was purchased from SigmaAldrich. ICI 182780 was kindly provided by Dr Alan Wakeling, Zeneca Pharmaceuticals (Macclesfield, Cheshire, UK). Mouse anti-human $\mathrm{ER} \alpha(\mathrm{Ab}-15) \mathrm{MAB}$ was purchased from NeoMarkers Inc. (Fremont, CA, USA). Goat anti-human VEGF (sc-152-G) and $\beta$-actin (sc-1615) were purchased from Santa Cruz Biotechnology Inc. (Santa Cruz, CA, USA). For ER $\alpha$ detection, an anti-mouse secondary antibody from Santa Cruz Biotechnology Inc. (sc2005) generated a nonspecific signal at $64 \mathrm{kDa}$, similar to the size of $E R \alpha$, when used alone (Marriott et al. 2007). Therefore, appropriate secondary antibodies conjugated to horseradish peroxidase that did not generate a nonspecific signal (Cat \# 626620; Zymed Inc., San Francisco, CA, USA) were used for immunoblotting. Nitrocellulose membranes were obtained from
Bio-Rad Laboratories. The Renaissance Western Blot Chemiluminescence Reagent Plus kit was obtained from Perkin-Elmer Life Science (Boston, MA, USA). X-Omatic films were purchased from American Imaging (South Plainfield, NJ, USA). TRI Reagent was obtained from Sigma-Aldrich. RNeasy Mini Kit and RNaseFree DNase Set were obtained from Qiagen Inc. SuperScript III First-Strand Synthesis System for RT-PCR was obtained from Invitrogen. SYBR Green PCR Master Mix was purchased from Applied Biosystems (Foster City, CA, USA). All other chemicals were purchased from Sigma-Aldrich and Invitrogen.

\section{Animals}

Yorkshire-Landrace gilts were obtained from the Swine Unit of the New Jersey Agricultural Experiment Station, Rutgers University, New Brunswick, NJ, USA. Gilts were randomly assigned to one of six treatment groups on PND 0 as follows: (1) Control (C; DMSO:ETOH 4:1 vehicle, given i.p., and PBS, given i.m., $n=6$ ); (2) $\mathrm{ICl} 182780(\mathrm{ICl} ; 1 \mathrm{mg} / \mathrm{kg}$ body weight (BW), given i.p. in DMSO:ETOH 4:1 vehicle as a single injection $2 \mathrm{~h}$ prior to start of hormone treatment, $n=4)$; (3) Estradiol-17 $\beta$ (E; $50 \mu \mathrm{g} / \mathrm{kg} \mathrm{BW,}$ given i.p. in DMSO:ETOH, 4:1 vehicle every $24 \mathrm{~h}$ for $48 \mathrm{~h}, n=6$ ); (4) ICl/E ( $n=3)$; (5) porcine RLX (R; $20 \mu \mathrm{g} / \mathrm{kg} \mathrm{BW}$, given i.m. in PBS every $6 \mathrm{~h}$ for $48 \mathrm{~h}, n=8)$; and (6) $\mathrm{ICl} / \mathrm{R}(n=5)$. During treatment, neonatal gilts were maintained with sows and allowed to suckle naturally. Timing, dosage, and route of $\mathrm{ICl}$ administration were based on studies in rodents (Gibson et al. 1991, Pillai et al. 1999). Additionally, ICl was effective in blocking the E-induced uterine growth response observed in neonatal gilts that received the same E treatment regimen for 2 days prior to collection of ER-positive uterine tissues on PND 14 (Yan et al. 2006a). The dose and timing of RLX administration were based on studies in prepubertal gilts and rodents (Hall et al. 1990, Pillai et al. 1999). Gilts were weighed and killed $3 \mathrm{~h}$ after the last injection on PND 2. Each uterus and cervix was trimmed free of fat and associated ligaments and weighed. Tissues were frozen in liquid nitrogen and stored at $-80{ }^{\circ} \mathrm{C}$. All procedures involving animals were reviewed and approved as appropriate by the Rutgers University Animal Care and Facilities Committee (Protocol \# 88-079). Procedures were conducted in accordance with the Guide for the Care and Use of Agricultural Animals in Agricultural Research and Teaching (1999; Federation of Animal Science Society, Savoy, IL, USA).

\section{Protein extraction and evaluation of ER $\alpha$ and VEGF expression}

Tissue samples were homogenized in ice-cold lysis buffer (4 ml/g tissue) containing 1\% Triton X-100, 10\% glycerol, $150 \mathrm{mM}$ Tris- $\mathrm{HCl}, 300 \mathrm{mM} \mathrm{NaCl}, 1 \mathrm{mM} \mathrm{MgCl}$, $\mathrm{pH}$ 7.5. The resulting tissue lysate was passed (five times) through a 20-gauge needle fitted to a syringe, incubated on ice for $1 \mathrm{~h}$ and centrifuged $\left(12000 \mathrm{~g}, 4^{\circ} \mathrm{C}\right)$ for $5 \mathrm{~min}$. Protein concentration of the supernatant was measured using a detergentcompatible protein assay kit (DC Protein Assay, Bio-Rad Laboratories). Tissue protein content was calculated based on the protein concentration and wet weight of the organ.

To document ER $\alpha$ and VEGF protein expression, uterine and cervical proteins $(30 \mu \mathrm{g})$ were resolved on $12.0 \%$ Bis-Tris- $\mathrm{HCl}$ buffered polyacrylamide electrophoresis gels under reducing 
conditions in the presence of SDS and transferred onto nitrocellulose membranes. After blocking in $10 \%$ nonfat dry milk in Tris-buffered saline containing Tween-20 (TBST; $25 \mathrm{mM}$ Tris (pH 7.5), $0.14 \mathrm{mM} \mathrm{NaCl}, 3 \mathrm{mM} \mathrm{KCl}, 0.05 \%$ Tween-20), membranes were probed with either mouse anti-human ER $\alpha$ antibody $(2 \mu \mathrm{g} / \mathrm{ml})$ or goat anti-human VEGFantibody $(0.2 \mu \mathrm{g} / \mathrm{ml})$ overnight at $4{ }^{\circ} \mathrm{C}$. After washing with TBST, blots were incubated with either horseradish peroxidase-conjugated anti-mouse $(0.3 \mu \mathrm{g} / \mathrm{ml})$ or anti-goat secondary antibody $(0.75 \mu \mathrm{g} / \mathrm{ml})$ for $1 \mathrm{~h}$ at room temperature, and bound antibodies were detected by ECL. Membranes were stripped with buffer $(100 \mathrm{mM}$ 2 - $\beta$-mercaptoethanol, $2 \% \mathrm{SDS}$, and $62.3 \mathrm{mM}$ Tris- $\mathrm{HCl}$ ) and reprobed with goat anti-human $\beta$-actin $(0.2 \mu \mathrm{g} / \mathrm{ml})$ to determine the amount of protein loaded on the gels. Signals on films were quantified using Scion image densitometric software (Scion Corporation, Frederick, MD, USA).

\section{RNA isolation and cDNA generation}

Total RNA was isolated from 30 to $50 \mathrm{mg}$ of tissue samples using TRI Reagent followed by RNeasy Mini Kit and traces of DNA were removed using the RNase-Free DNase Set. RNA concentration and purity were evaluated by spectrophotometry. RNA integrity was checked by agarose gel electrophoresis and ethidium bromide staining to visualize sharp, clear $28 \mathrm{~S}$ and $18 \mathrm{~S}$ rRNA bands. RT was performed with $5 \mu \mathrm{g}$ RNA per sample using the (PTC-200) Peltier Thermal Cycler (Bio-Rad Laboratories Inc.) and SuperScript III First-Strand Synthesis System for RT-PCR. All procedures were carried out following manuals/guidelines provided by the manufacturers.

\section{Real time quantitative $R T-P C R$}

Real time quantitative RT-PCR (qRT-PCR) was performed using an Applied Biosystems Gene Amp 7000 Sequence Detection System and the SYBR Green method following universal thermal cycling parameters recommended by the manufacturer. Primers for quantitative qRT-PCR were designed using Primer Express Software (Applied Biosystems) and synthesized by Invitrogen Corp. Porcine RXFP1 (GenBank accession number: CA994862) forward - 5'-GCATCACTTTGAGGCAGAGACA- $3^{\prime}$ - and reverse - 5'-CCTCGGCAAAGACATTGCAT-3' - primers were used to generate a $69 \mathrm{bp}$ amplicon. Similarly, porcine cyclophilin (GenBank accession number: AU058466) forward - 5'-TTATAAAGGTTCCTGCTTTCACAGAA-3' - and reverse 5'-TGCCATTATGGCGTGTGAAG-3' - primers were used to generate an expected $77 \mathrm{bp}$ amplicon. To ensure specific amplification, multiple controls including water only, no primers and no template were included in assays. Primer quality was evaluated by amplifying serial dilutions of the cDNA template $(1,1: 2,1: 5,1: 10)$ and dissociation curves for each set of primers were checked to ensure that there was no amplicon-independent amplification (i.e., generation of primer dimers). The PCR amplification products were analyzed by agarose gel electrophoresis to further confirm the absence of nonspecific amplification. Values for cycle threshold $\left(C_{\mathrm{T}}\right)$, the point at which exponential amplification of the PCR products begins, were determined using Applied Biosystems software. Porcine cyclophilin was used as an internal control in qRT-PCR analyses to normalize cDNA input and PCR efficiency. Data were analyzed by the comparative CT method $\left(\Delta \Delta C_{\mathrm{T}}\right)$ for relative quantitation of gene expression in which the sample having the minimum expression level was chosen as the reference calibrator (Livak \& Schmittgen 2001). Therefore, data from these analyses are presented as relative expression levels.

\section{Statistical analyses}

All quantitative data were subjected to analyses of variance using general linear model procedures available with SAS (SAS 2002-2003). For uterine and cervical wet weight, protein content and both $E R \alpha$ (ESR1) and VEGF gene expression data, generated by densitometry of Western blots, statistical models considered variation due to the main effects of treatment, including pretreatment with $\mathrm{ICl}$. Treatment effects were identified by performing a set of preplanned contrasts that included comparisons of specific groups as follows: control versus $\mathrm{E}$; control versus $\mathrm{RLX}$; E versus ICl; E versus ICI/E; and $\mathrm{R}$ versus $\mathrm{ICI} / \mathrm{R}$. When results of these analyses indicated a likely main effect of $\mathrm{ICl}$ and potential differences in the magnitude of E- and RLX-induced effects, a second set of contrasts was run with comparisons that included: control versus $\mathrm{ICl}$ and $\mathrm{E}$ versus $\mathrm{R}$. Analyses of uterine and cervical RXFP1 expression data, evaluated at the transcriptional level, considered variation due to the main effects of $E, R L X$, and their interactions. All error terms were identified based upon the expectations of the mean squares for error and data were expressed as least square means with standard errors.

\section{Acknowledgements}

This work was supported by USDA-NRI-99-35203-7812 and USDA-NRI-2003-35203-13572 to FFB and CAB, NSF EPS0447675 to $F \mathrm{~F} \mathrm{~B}$ and the $\mathrm{NJ}$ and $\mathrm{AL}$ Agricultural Experiment Stations. The authors thank Dr Alan Wakeling, Zeneca Pharmaceuticals, Cheshire, UK for providing ICI 182780 and the staff of the Rutgers University Animal Care Program for their assistance in these studies. The authors declare that there is no conflict of interest that would prejudice the impartiality of this scientific work.

\section{References}

Adams WC, Hanousek CA \& Frieden EH 1989 Progesterone inhibits the uterotrophic effect of relaxin in immature rats. Proceedings of the Society for Experimental Biology and Medicine 191 159-162.

Bartol FF, Wiley AA \& Bagnell CA 2006 Uterine development and endometrial programming. Society of Reproduction and Fertility 62 113-130.

Bartsch O, Bartlick B \& Ivell R 2004 Phosphodiesterase 4 inhibition synergizes with relaxin signaling to promote decidualization of human endometrial stromal cells. Journal of Clinical Endocrinology and Metabolism 89 324-334.

Bathgate RA, Ivell R, Sanborn BM, Sherwood OD \& Summers RJ 2006 International Union of Pharmacology LVII: recommendations for the nomenclature of receptors for relaxin family peptides. Pharmacological Reviews $\mathbf{5 8}$ 7-31.

Cardenas H \& Pope WF 2005 Estrogen receptors in the uterus and ovarian follicles of gilts treated with dihydrotestosterone. Domestic Animal Endocrinology 29 523-533. 
Couse JF \& Korach KS 1999 Estrogen receptor null mice: what have we learned and where will they lead us? Endocrine Reviews 20 358-417.

Cullinan-Bove K \& Koos RD 1993 Vascular endothelial growth factor/vascular permeability factor expression in the rat uterus: rapid stimulation by estrogen correlates with estrogen-induced increases in uterine capillary permeability and growth. Endocrinology 133 829-837.

Downing SJ \& Hollingsworth M 1992 Influence of ovarian steroids on myometrial sensitivity and tolerance to relaxin in the rat in vivo: lack of cross-tolerance between relaxin, salbutamol and cromakalim. Journal of Endocrinology 135 17-28.

Downing SJ \& Hollingsworth M 1993 Uptake of relaxin in the uterus and cervix of rats in vivo: influence of ovarian steroids and tolerance. Journal of Reproduction and Fertility 99 121-129.

Einspanier A 2001 Relaxin is an important factor for uterine differentiation and implantation in the marmoset monkey. In Relaxin 2000, pp 73-82. Eds GW Tregear, R Ivell, RA Bathgate \& JD Wade. Dordrecht: Kluwer Academic Publishers.

Fleming JG, Spencer TE, Safe SH \& Bazer FW 2006 Estrogen regulates transcription of the ovine oxytocin receptor gene through GC-rich SP1 promoter elements. Endocrinology 147 899-911.

Gibson MK, Nemmers LA, Beckman WC Jr, Davis VL, Curtis SW \& Korach KS 1991 The mechanism of ICI 164384 antiestrogenicity involves rapid loss of estrogen receptor in uterine tissue. Endocrinology 129 2000-2010.

Glatstein IZ \& Yeh J 1995 Ontogeny of the estrogen receptor in the human fetal uterus. Journal of Clinical Endocrinology and Metabolism 80 958-964.

Glidewell-Kenney C, Weiss J, Lee EJ, Pillai S, Ishikawa T, Ariazi EA \& Jameson JL 2005 ERE-independent ERalpha target genes differentially expressed in human breast tumors. Molecular and Cellular Endocrinology 245 53-59.

Hall JA \& Anthony RV 1993 Influence of ovarian steroids on relaxininduced distensibility and compositional changes in the porcine cervix. Biology of Reproduction 48 1348-1353.

Hall JA, Cantley TC, Day BN \& Anthony RV 1990 Uterotropic actions of relaxin in prepubertal gilts. Biology of Reproduction 42 769-774.

Hsu SY, Nakabayashi K, Nishi S, Kumagai J, Kudo M, Sherwood OD \& Hsueh AJW 2002 Activation of orphan receptors by the hormone relaxin. Science 295 671-674.

Kim K, Thu N, Saville B \& Safe S 2003 Domains of estrogen receptor alpha (ERalpha) required for ERalpha/Sp1-mediated activation of GC-rich promoters by estrogens and antiestrogens in breast cancer cells. Molecular Endocrinolgy 17 804-817.

Livak KJ \& Schmittgen TD 2001 Analysis of relative gene expression data using real-time quantitative PCR and the $2(-$ Delta Delta $C(\mathrm{~T}))$ method. Methods 25 402-408.

Markey CM, Wadia PR, Rubin BS, Sonnenschein C \& Soto AM 2005 Longterm effects of fetal exposure to low doses of the xenoestrogen bisphenolA in the female mouse genital tract. Biology of Reproduction 72 1344-1351.

Marriott LK, McGann-Gramling KR, Hauss-Wegrzyniak B, Sheldahl LC, Shapiro RA, Dorsa DM \& Wenk GL 2007 Brain infusion of lipopolysaccharide increases uterine growth as a function of estrogen replacement regimen: suppression of uterine estrogen receptor-alpha by constant, but not pulsed, estrogen replacement. Endocrinology 148 232-240.

Masters RA, Crean BD, Yan W, Moss AG, Ryan PL, Wiley AA, Bagnell CA \& Bartol FF 2007 Neonatal porcine endometrial development and epithelial proliferation affected by age and exposure to estrogen and relaxin. Domestic Animal Endocrinology 33 335-346.

Mazella J, Tang M \& Tseng L 2004 Disparate effects of relaxin and TGFbeta1: relaxin increases, but TGFbeta1 inhibits, the relaxin receptor and the production of IGFBP-1 in human endometrial stromal/decidual cells. Human Reproduction 19 1513-1518.

Mercado-Simmen RC, Bryant-Greenwood GD \& Greenwood FC 1982 Relaxin receptor in the rat myometrium: regulation by estrogen and relaxin. Endocrinology $110220-226$.

Milanini J, Vinals F, Pouyssegur J \& Pages G 1998 p42/p44 MAP kinase module plays a key role in the transcriptional regulation of the vascular endothelial growth factor gene in fibroblasts. Journal of Biological Chemistry 273 18165-18172.
Miller C, Degenhardt K \& Sassoon DA 1998 Fetal exposure to DES results in de-regulation of Wnt7a during uterine morphogenesis. Nature Genetics 20 228-230.

Mowa CN \& Iwanaga T 2000 Differential distribution of oestrogen receptor-alpha and -beta mRNAs in the female reproductive organ of rats as revealed by in situ hybridization. Journal of Endocrinology 165 59-66.

Nikaido Y, Danbara N, Tsujita-Kyutoku M, Yuri T, Uehara N \& Tsubura A 2005 Effects of prepubertal exposure to xenoestrogen on development of estrogen target organs in female CD-1 mice. In Vivo 19 487-494.

Okada A, Sato T, Ohta Y \& Iguchi T 2005 Sex steroid hormone receptors in the developing female reproductive tract of laboratory rodents. Journal of Toxicological Science $\mathbf{3 0} 75-89$.

Parry LJ, McGuane JT, Gehring HM, Kostic IGT \& Siebel AL 2005 Mechanisms of relaxin action in the reproductive tract: studies in the relaxin-deficient $(\mathrm{Rlx}-/-)$ mouse. Annals of the New York Academy of Science 1041 91-103

Pillai SB, Rockwell LC, Sherwood OD \& Koos RD 1999 Relaxin stimulates uterine edema via activation of estrogen receptors: blockade of its effects using ICI 182 780, a specific estrogen receptor antagonist. Endocrinology $1402426-2429$

Pillai SB, Jones JM \& Koos RD 2002 Treatment of rats with 17beta-estradiol or relaxin rapidly inhibits uterine estrogen receptor beta1 and beta2 messenger ribonucleic acid levels. Biology of Reproduction 67 1919-1926.

Porter DG, Ryan PL \& Norman L 1992 Lack of effect of relaxin on oxytocin output from the porcine neural lobe in vitro or in lactating sows in vivo. Journal of Reproduction and Fertility 96 251-260.

SAS 2002-2003 SAS/STAT User's Guide, Cary, NC: SAS Institute Inc.

Schonfelder G, Flick B, Mayr E, Talsness C, Paul M \& Chahoud I 2002 In utero exposure to low doses of bisphenol A lead to long-term deleterious effects in the vagina. Neoplasia 4 98-102.

Sherwood OD 2004 Relaxin's physiological roles and other diverse actions. Endocrine Reviews 25 205-234.

Sherwood CD \& O'Byrne EM 1974 Purification and characterization of porcine relaxin. Archives of Biochemistry and Biophysics 160 185-196.

Shi Q, Le X, Abbruzzese JL, Peng Z, Qian CN, Tang H, Xiong Q, Wang B, Li XC \& Xie K 2001 Constitutive Sp1 activity is essential for differential constitutive expression of vascular endothelial growth factor in human pancreatic adenocarcinoma. Cancer Research 61 4143-4154.

Shipman-Appasamy PM, Cohen KS \& Prystowsky MB 1991 Nucleotide sequence of murine PCNA: interspecies comparison of the CDNA and the $5^{\prime}$ flanking region of the gene. DNA Sequence 2 181-191.

Siebel AL, Gehring HM, Reytomas IGT \& Parry LJ 2003 Inhibition of oxytocin receptor and estrogen receptor-alpha expression, but not relaxin receptors (LGR7), in the myometrium of late pregnant relaxin gene knockout mice. Endocrinology 144 4272-4275.

Spencer TE, Wiley AA \& Bartol FF 1993 Neonatal age and period of estrogen exposure affect porcine uterine growth, morphogenesis, and protein synthesis. Biology of Reproduction 48 741-751.

Suzuki A, Sugihara A, Uchida K, Sato T, Ohta Y, Katsu Y, Watanabe H \& Iguchi T 2002 Developmental effects of perinatal exposure to bisphenol$A$ and diethylstilbestrol on reproductive organs in female mice. Reproductive Toxicology 16 107-116.

Tarleton BJ, Wiley AA, Spencer TE, Moss AG \& Bartol FF 1998 Ovaryindependent estrogen receptor expression in neonatal porcine endometrium. Biology of Reproduction 58 1009-1019.

Tarleton BJ, Wiley AA \& Bartol FF 1999 Endometrial development and adenogenesis in the neonatal pig: effects of estradiol valerate and the antiestrogen ICI 182 780. Biology of Reproduction 61 253-263.

Tarleton BJ, Wiley AA \& Bartol FF 2001 Neonatal estradiol exposure alters uterine morphology and endometrial transcriptional activity in prepubertal gilts. Domestic Animal Endocrinology 21 111-125.

Tarleton BJ, Braden TD, Wiley AA \& Bartol FF 2003 Estrogen-induced disruption of neonatal porcine uterine development alters adult uterine function. Biology of Reproduction 68 1387-1393.

Unemori EN, Erikson ME, Rocco SE, Sutherland KM, Parsell DA, Mak J \& Grove BH 1999 Relaxin stimulates expression of vascular endothelial growth factor in normal human endometrial cells in vitro and is associated with menometrorrhagia in women. Human Reproduction $\mathbf{1 4}$ 800-806. 
Unemori EN, Lewis M, Constant J, Arnold G, Grove BH, Normand J, Deshpande U, Salles A, Pickford LB, Erikson ME, et al. 2000 Relaxin induces vascular endothelial growth factor expression and angiogenesis selectively at wound sites. Wound Repair and Regeneration 8 361-370.

Vasilenko P \& Mead JP 1987 Growth-promoting effects of relaxin and related compositional changes in the uterus, cervix, and vagina of the rat. Endocrinology 120 1370-1376.

Vasilenko P III, Frieden EH \& Adams WC 1980 Effect of purified relaxin on uterine glycogen and protein in the rat. Proceedings of the Society for Experimental Biology and Medicine 163 245-248.

Wiqvist N \& Paul KG 1958 Inhibition of the spontaneous uterine motility in vitro as a bioassay of relaxin. Acta Endocrinologica 29 135-146.

Yamashita S, Newbold RR, McLachlan JA \& Korach KS 1989 Developmental pattern of estrogen receptor expression in female mouse genital tracts. Endocrinology 125 2888-2896.
Yan W, Ryan PL, Bartol FF \& Bagnell CA 2006a Uterotrophic effects of relaxin related to age and estrogen receptor activation in neonatal pigs. Reproduction 131 943-950.

Yan W, Wiley AA, Bathgate RAD, Frankshun A-L, Lasano S, Crean BD, Steinetz BG, Bagnell CA \& Bartol FF 2006b Expression of LGR7 and LGR8 by neonatal porcine uterine tissues and transmission of milk-borne relaxin into the neonatal circulation by suckling. Endocrinology 147 4303-4310.

Received 9 January 2008

First decision 28 January 2008

Accepted 15 February 2008 